\title{
Langerhans cell histiocytosis: A rare cause of pathological rib fracture
}

\author{
Langerhans hücreli histiyositoz: Patolojik kaburga kırığının nadir bir nedeni

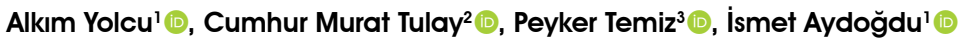 \\ 'Department of Internal Medicine, Manisa Celal Bayar University, Faculty of Medicine, Manisa, Turkey \\ 2Department of Thoracic Surgery, Manisa Celal Bayar University, Faculty of Medicine, Manisa, Turkey \\ ${ }^{3}$ Department of Pathology, Manisa Celal Bayar University, Faculty of Medicine, Manisa, Turkey
}

\begin{abstract}
Langerhans cell histiocytosis, formerly known as histiocytosis $\mathrm{X}$, represents clonal proliferations of the antigen-presenting dendritic cells, which are normally found in many organs. It is a rare disease which tends to affect children and adolescents. In particular, adult-onset type is very rare. Herein, we present a female adult diagnosed with Langerhans cell histiocytosis of the rib without any systemic involvement which was successfully treated with surgery.
\end{abstract}

Keywords: Bone lesion; chest pain; Langerhans cell histiocytosis.

Langerhans cell histiocytosis $(\mathrm{LCH})$ is a clonal neoplastic proliferation of the Langerhans type cells, expressing CD1a, Langerin, and S100 protein and showing the presence of Birbeck granules in the ultrastructural examination. Most cases are diagnosed in childhood, approximately five cases per million children. On the other hand, the annual incidence is estimated 1 to 2 cases per million adults. ${ }^{[1-3]}$ The disease can affect the skin, bone, lymph node, spleen, liver, and central nervous system. The clinical symptoms of LCH depend on the site and extent of involvement. The disease may be focal or systemic. The spectrum of clinical presentations ranges from a single bone lesion to a disseminated disease. ${ }^{[1-3]}$

In this article, we report an unusual location of $\mathrm{LCH}$, only at the rib, which was successfully treated with surgery in an adult patient.

\section{$\ddot{O} Z$}

Daha önceleri histiyositoz X olarak da bilinen Langerhans hücreli histiyositoz, normalde birçok organda bulunan antijen sunan dendritik hücrelerin klonal proliferasyonlarını temsil eder. $\mathrm{Bu}$, çocukları ve ergenleri etkileme eğiliminde olan nadir bir hastalıktır. Özellikle, erişkin başlangıçlı formu çok nadirdir. Bu yazıda, herhangi bir sistemik tutulumu olmayan, kostal Langerhans hücreli histiyositoz tanısı konan ve cerrahi ile başarılı bir şekilde tedavi edilen erişkin bir kadın olgu sunuldu.

Anahtar sözcükler: Kemik lezyonu; göğüs ağrısı; Langerhans hücreli histiyositoz.

\section{CASE REPORT}

An otherwise healthy, 32-year-old female patient was admitted to the Department of Thoracic Surgery with right-side chest pain. The pain began one year earlier and was progressively getting worse, particularly over the last month. There was no history of trauma. Her medical history was non-specific and there was no family history of malignancy. Due to persistent pain, thoracic computed tomography (CT) showed a fracture line on the posterolateral area of the right $10^{\text {th }}$ rib (Figure 1). A year-long progression of chest pain, pathological fracture line, and surrounding soft tissue enlargement indicated the possibility of a bone tumor. However, there were no abnormal hypermetabolic lesions on positron emission tomography (PET)-CT. A written informed consent was obtained from the patient. The $10^{\text {th }}$ rib was removed by partial rib resection for diagnostic confirmation and treatment.

Received: March 22, 2020 Accepted: May 31, 2020 Published online: January 13, 2021

Correspondence: Cumhur Murat Tulay, MD. Manisa Celal Bayar Üniversitesi Tıp Fakültesi, Göğüs Cerrahisi Anabilim Dalı, 45030 Yunusemre, Manisa, Türkiye. Tel: +90236-2360330 e-mail: cumhurtulay@hotmail.com 

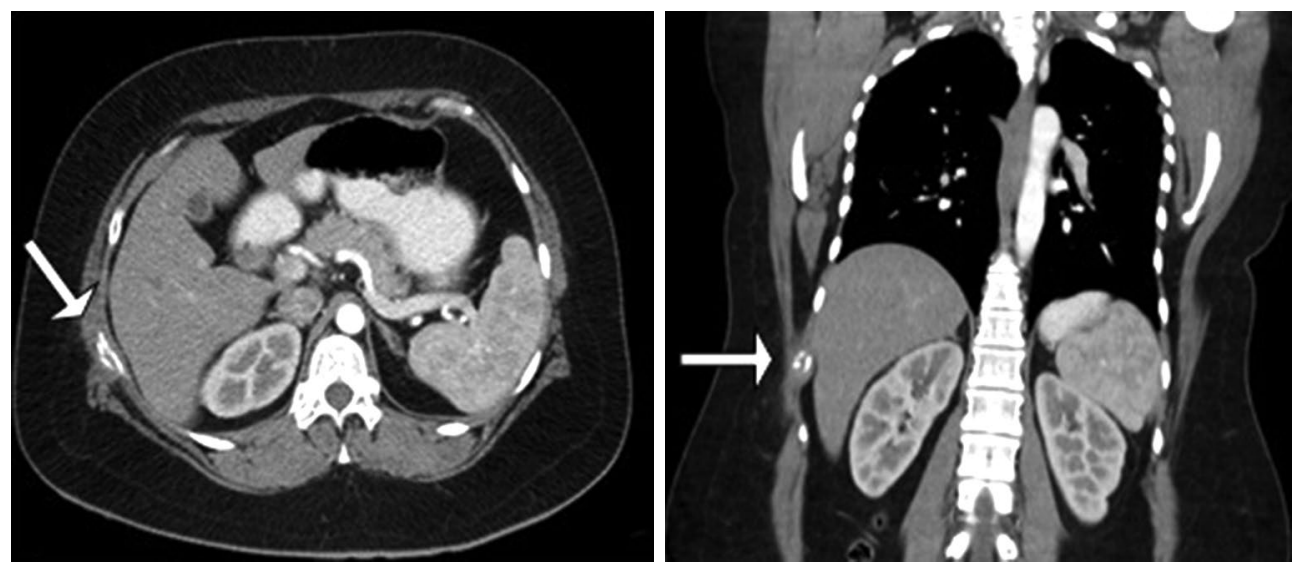

Figure 1. Thoracic computed tomography scans showing a focal non-displaced fracture line on right $10^{\text {th }}$ rib. Arrows indicate coronal and axial planes.

The pathology report was unexpectedly compatible with LCH (Figure 2). The rib resection material was $10 \times 6 \times 3.5 \mathrm{~cm}$ in total, consisting of the surrounding soft tissues and rib. The defined area was $3-\mathrm{cm}$ away from the surgical margin. The lesion was composed of cells with large eosinophilic cytoplasm, vesicular nuclei, immunohistochemically positive staining for S-100, CD1a, and Langerin, as well as multinuclear giant cells stained with CD68 and diffuse eosinophils, which are clustered in places. Based on these findings, the patient was referred to the Department of Hematology.

During system evaluation, no dyspnea or tachypnea, polydipsia, and polyuria, lymphadenopathy, hepatosplenomegaly, weight loss, fever, gingival hypertrophy or ataxia was found. The body temperature, heart rate, blood pressure, and respiratory rate were all within the normal range. No clinical findings could be detected. Complete blood count and the blood
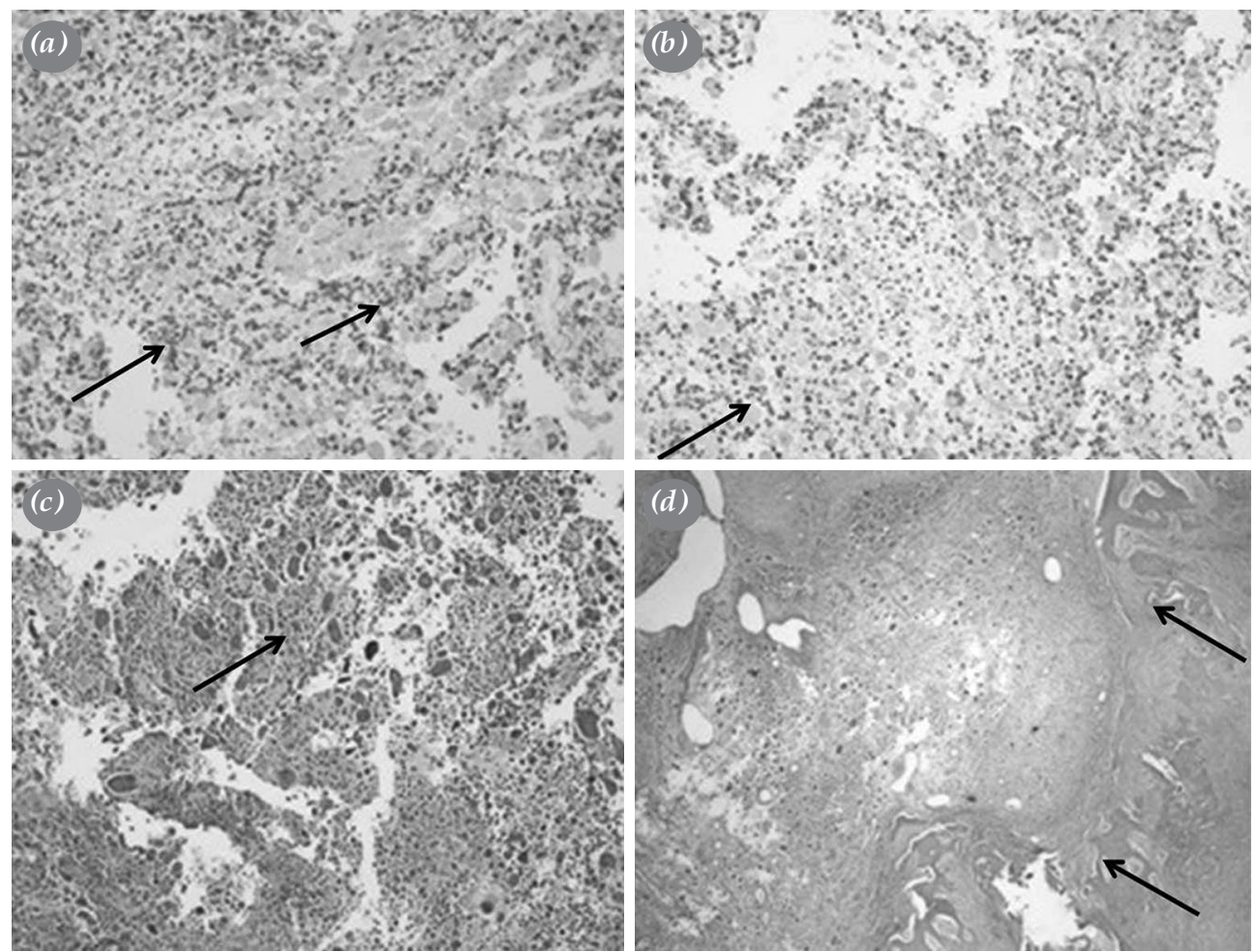

Figure 2. (a) CD1a positivity in tumor cells $(\times 100)$, (b) Langerin positivity in tumor cells $(\times 100)$ [Positive stained cells shown with the arrow], (c) Tumor cells with eosinophilic cytoplasm, vesicular nucleus and multinuclear cells $(\mathrm{H}-\mathrm{E} \times 100)$, (d) Tumor which destroys bone $(\mathrm{H}-\mathrm{E} \times 40)$. 
biochemical tests were within the normal range. Peripheral smear was examined, and no significant findings were found. A skeletal survey was negative for any other bone involvement. The endocrinological evaluation of the patient was made with blood tests and cranial magnetic resonance imaging (MRI), particularly in terms of diabetes insipidus and there was no pathological finding.

On radiological examination with whole-body skeletal survey and abdominal CT scan, there was no visceral lesion. The patient was thought to have unifocal involvement of $\mathrm{LCH}$; therefore, no radiotherapy or chemotherapy was considered and was followed in the outpatient clinic. During follow-up for five months, the patient had no local recurrence or distant metastasis. She has remained asymptomatic during follow-up.

\section{DISCUSSION}

Langerhans cell histiocytosis includes a broad spectrum of clinical manifestations in children and adults, ranging from self-limited lesions to life-threatening disseminated disease. It may involve a single organ (single-system LCH), which may be a single site (unifocal) or involve multiple sites (multifocal) or it may involve multiple organs (multisystem LCH), affecting a limited number of organs or be disseminated. ${ }^{[1]}$ In some case series, it is defined that bone lesions are predominantly observed in male patients, and other organ systems are involved in female patients. ${ }^{[4]}$ The primary sites of bone involvement of $\mathrm{LCH}$ in adults, the ratios are as follows: mandible $30 \%$, skull $21 \%$, vertebrae $13 \%$, pelvis $13 \%$, extremities $17 \%$, and ribs $6 \% .^{[5]}$ It is most commonly seen in the head, but at least in the rib. Due to its similarity to radiological osteolytic lesions, $\mathrm{LCH}$ is difficult to differentiate from other bone tumors and benign lesions. The radiological findings of our patient were a fractured rib and coexistence of soft tissue swelling without osteolytic appearance. In such cases, it may come to mind whether these ratios are in patients with just solitary osseous lesions without extraosseous LCH or not, although there is no clear information about it. Also, lymphoma or lung carcinomas may be seen with $\mathrm{LCH} \cdot{ }^{[4]}$ In our case, we observed no additional pathology or malignancy.

Considering the general characteristics of the disease, we consider that our patient with being a female adult and having a single bone lesion is one of the few cases in the literature. ${ }^{[5-9]}$ Current data for the treatment of adults with $\mathrm{LCH}$ are limited to case reports and case series with no prospective clinical trials to inform therapeutic strategies. ${ }^{[1]}$ Several numbers of approaches, including radiation, and various chemotherapy regimens, steroids, surgery or combinations of these treatment modalities, were used to treat $\mathrm{LCH} .{ }^{[10]}$ Surgical treatment includes commonly curettage of bone or excision of lymph nodes. Patients with a solitary osseous lesion have the best prognosis compared to those with LCH involvement of other systems. ${ }^{[4]}$ In our case, partial resection of the rib was performed, as the patient had persistent pain for months and a pathological fracture line surrounding soft tissue enlargement. After examination, no additional involvement site was detected in our patient and diagnosed with a single lesion-LCH.

In conclusion, surgical excision is kept in mind as an effective treatment for Langerhans cell histiocytosis, particularly in patients with solitary bone lesions.

\section{Declaration of conflicting interests}

The authors declared no conflicts of interest with respect to the authorship and/or publication of this article.

\section{Funding}

The authors received no financial support for the research and/or authorship of this article.

\section{REFERENCES}

1. Allen CE, Ladisch S, McClain KL. How I treat Langerhans cell histiocytosis. Blood 2015;126:26-35.

2. Tombak A, Tiftik EN. Langerhans Hücreli Histiositozis. Turkiye Klinikleri J Hematol-Special Topics 2013;6:74-9.

3. Baumgartner I, von Hochstetter A, Baumert B, Luetolf U, Follath F. Langerhans'-cell histiocytosis in adults. Med Pediatr Oncol 1997;28:9-14.

4. Howarth DM, Gilchrist GS, Mullan BP, Wiseman GA, Edmonson JH, Schomberg PJ. Langerhans cell histiocytosis: diagnosis, natural history, management, and outcome. Cancer 1999;85:2278-90.

5. Kim SH, Choi MY. Langerhans cell histiocytosis of the rib in an adult: A case report. Case Rep Oncol 2016;9:83-8.

6. Götz G, Fichter J. Langerhans'-cell histiocytosis in 58 adults. Eur J Med Res 2004;9:510-4.

7. Gkrouzman E, Cuadra RH, Jacob J. Langerhans cell histiocytosis of the bone presenting as back pain: An unusual diagnosis for a common complaint. Conn Med 2015;79:409-14.

8. Shimoyama T, Kimura B, Nakamura K, Yamada T, Kawachi $\mathrm{H}$. Langerhans cell histiocytosis of the rib in adult male. Kyobu Geka 2011;64:135-8.

9. Gómez Sánchez-Biezma C, Pintor Holguín E, Téllez Molina MJ, Llamas Gascón E, Unifocal Langerhans cell granulomatosis in a young woman. An Med Interna 2000;17:494-5.

10. Cantu MA, Lupo PJ, Bilgi M, Hicks MJ, Allen CE, McClain KL. Optimal therapy for adults with Langerhans cell histiocytosis bone lesions. PLoS One 2012;7:e43257. 